\title{
ANALISIS STRUKTURAL PADA PUISI MALU AKU JADI ORANG INDONESIA KARYA TAUFIQ ISMAIL (PENDEKATAN STRUKTURAL)
}

\author{
Nori Anggraini ${ }^{1}$, Nurlaely Aulia ${ }^{2}$ \\ Universitas Muhammadiyah Tangerang \\ nory_agg@yahoo.com ${ }^{1}$, aulianurlaely@gmail.com ${ }^{2}$
}

\begin{abstract}
Abstrak
Penelitian ini bertujuan untuk menganalisis struktur fisik dan batin puisi yang terdapat pada puisi Malu Aku Jadi Orang Indonesia yang bertema tentang kedaulatan rakyat. Penelitian ini menggunakan pendekatan kualitatif dan metode analisis isi untuk menganalisis unsur fisik dan batin puisi. Dalam penelitian ini sumber data yang digunakan sebagai objek analisis menggunakan satu puisi dari buku kumpulan puisi Malu Aku Jadi Orang Indonesia yang berjudul Malu Aku Jadi Orang Indonesia karya Taufiq Ismail. Hasil penelitian yang didapatkan terdapat unsur fisik dan batin pada puisi Malu Aku Jadi Orang Indonesia. Temuan yang dari unsur fisik terdapat lima diksi, dua imaji, tiga kata konkret, dua gaya bahasa perbandingan dan gaya bahasa penegasan yang masing-masing memiliki bagian, terdapat dua rima atau irama, dan dua tipografi. Temuan dari unsur batin puisi terdapat satu tema, satu nada, tiga rasa dan satu amanat. Unsur fisik yang mendominasi dalam temuan penelitian adalah penggunaan diksi yang digunakan penyair, sedangkan unsur batin yang mendominasi adalah rasa dalam puisi bagaimana seorang penyair menyampaikan rasa kepada pembaca melalui tulisan.
\end{abstract}

Kata Kunci: unsur fisik, unsur batin, puisi

\section{Pendahuluan}

Sastra merupakan suatu karya yang mengandung struktur seni. Sastra juga diartikan sebagai ekspresi jiwa manusia yang mampu memberikan rasa indah dan melahirkan rasa kagum bagi orang yang menikmatinya, tetapi sering kali karya sastra itu tidak mampu dinikmati dan dipahami sepenuhnya oleh sebagian masyarakat (Mulasih, 2017:52). Sastra memiliki fungsi sebagai cermin kehidupan yang mampu memantulkan nilai-nilai yang digunakan dalam masyarakat khususnya pada individu maupun masyarakat. Sastra dan kehidupan merupakan suatu keterpaduan yang saling melengkapi karena sastra hidup dalam jiwa manusia dan manusia membutuhkan sastra dalam menuangkan buah pikirannya. Karya sastra yang dikenal oleh 
masyarakat memiliki banyak jenisnya seperti puisi, novel, cerpen, drama. Masingmasing jenis karya sastra tersebut sangat berpengaruh terhadap perkembangan sastra yang kian hari semakin berkembang.

Salah satu karya sastra yang akan dianalisis yaitu puisi. Puisi adalah suatu karya sastra yang memiliki ungkapan dan pemikiran, biasanya puisi disampaikan dengan bahasa yang indah. Sulkifli (2016:2) mengatakan puisi adalah bahasa perasaan, yang dapat memadukan suatu respon yang mendalam dalam beberapa kata. Sesuai hakikatnya puisi memiliki bahasa yang padat, indah, dan tidak langsung pada setiap baitnya yang bertujuan untuk membumbui suatu makna yang terselip dalam pusi. Kehadiran sebuah puisi menciptakan suasana perasaan intensif. Puisi juga dapat mendasarkan masalah atau berbagai hal yang menyentuh kesadaran. Puisi memiliki struktur pembangun untuk menciptakan puisi menjadi lebih berkesan dan sistematis. Struktur pembangun puisi terbagi menjadi dua yaitu struktur fisik dan struktur batin puisi.

Struktur fisik puisi adalah struktur pembangun puisi yang bersifat fisik atau nampak dalam bentuk susunan kata-katanya atau bisa dikatakan sebagai sarana yang digunakan oleh seoarang penyair untuk mengungkapkan hakikat puisi. Wahyuni dan Mohammad (2018:117) menjelaskan bahwa struktur fisik puisi adalah struktur yang terlihat dari puisi tersebut secara kasat mata. Struktur fisik puisi terbagi enam bagian yaitu diksi, imaji, kata konkret, gaya bahasa atau majas, rima atau irama, dan tipografi atau perwajahan. Diksi merupakan pengolahan atau pemilihan kata yang digunakan sehingga puisi memiliki nilai estetika yang tinggi. Imaji merupakan cara yang diguanakan oleh seoarang penyair dalam penggunaan indera manusia, seperti imaji penglihatan, imaji pendengaran, imaji perabaan, imaji pengecapan, imaji penciuman. Kata konkret merupakan cara yang dilakukan penyair dalam mengartikan suatu kata secara menyeluruh. Gaya bahasa digunakan oleh seoarang penyair dengan menggunakan bahasa yang bersifat seolah-olah menghidupan dan menimbulkan makna konotasi dengan menggunakan bahasa yang figuratif. Melalui rima atau irama penyair mengolah kata dalam setiap lariknya sehingga terjadi persamaan bunyi baik 
di awal, tengah atau pada bagian akhir larik puisi. Tipografi atau perwajahan digunakan untuk mengetahui aspek visual puisi dengan mengetahui tata hubungan dan tata baris dalam sebuah puisi.

Sedangkan struktur batin puisi merupakan struktur pembangun puisi yang membangun dari dalam. Struktur batin puisi dapat dikatakan sebagai isi atau makna yang mengungkapkan apa yang hendak dikemukakan oleh penyair (Kamilah, dkk, 2016:2). Struktur batin puisi terbagi menjadi empat yaitu tema, rasa, nada, dan amanat. Melalui sebuah tema seorang penyair menyampaikan gagasan yang dikembangkan melalui sajak-sajaknya baik berupa makna setiap bait maupun secara keseluruhan. Rasa dalam sebuah puisi membuat penyair menyelipkan suatu sikap terhadap permasalahan yang terdapat dalam puisi. Ungkapan suatu tema dan rasa memiliki hubungan yang erat terhadap wawasan penyair yang dapat dilihat dari latar belakang sosial maupun secara psikologinya. Nada yang digunakan penyair menyalurkan suatu sikap kepada pembaca yang berhubungan dengan tema dan rasa yang disampaikan, dapat menggunakan nada yang tinggi atau sombong dan menganggap rendah seorang pembaca. Amanat dalam puisi dibuat oleh penyair untuk menyampaikan maksud dan tujuan yang disampaikan kepada pembaca melalui pesan tersirat yang terdapat dalam isi puisi, dengan demikian perlu sekali mengkaji sebuah puisi ketika ingin membacakannya agar pesan yang disampaikan bisa diterima dan dipahami pembaca.

Penelitian mengenai struktur puisi sudah banyak dilakukan oleh peneliti salah satunya adalah Wahyuni dan Mohammad yang menganalisis tentang Struktur Fisik dan Struktur Batin Puisi Anak dalam Majalah Potret Anak Cerdas. Namun, pada penelitian ini objeknya yaitu buku kumpulan puisi Taufiq Ismail yang berjudul Malu Aku Jadi Orang Indonesia, sedangkan pada penelitian yang sudah dilakukan objeknya adalah majalah Potret. Persamaan pada penelitian ini terletak pada apa yang akan dikaji yaitu struktur fisik dan batin puisi. 


\section{Metode Penelitian}

Penelitian ini menggunakan pendekatan struktural. Pendekatan struktural dinamakan pendekatan objektif, pendekatan formal, atau pendekatan analitik, bertolak dari asumsi dasar bahwa karya sastra kreatif memiliki otonomi yang penuh yang harus dilihat sebagai suatu sosok yang berdiri sendiri terlepas dari hal-hal lain yang berada di luar dirinya (Wirawan, 2016:41). Sulaeman dan Goziyah (2019:226) menyatakan bahwa analisis isi merupakan pesan atau informasi yang diperoleh dicatat secara sistematis, kemudia diinterpretasikan oleh peneliti, adapun dalam penelitian analisis isi objektivitas peneliti sangat diperlukan agar pemahaman mengenai sebuah isi dapat benar-benar terwujud. Data yang digunakan dalam penelitian ini berupa data sekunder dengan mengambil data tidak secara langsung diperoleh. Data sekunder sumber data yang diperoleh dengan cara membaca, mempelajari, memahami melalui media lain yang bersumber dari literature, bukubuku serta dokumen. Data sekunder pada penelitian ini menggunakan buku-buku referensi dan objek penelitian. Husein (2005:303) mengungkapkan objek penelitian berkaitan dengan apa atau siapa yang menjadi objek penelitian. Juga di mana dan kapan penelitian dilakukan, bisa juga ditambahkan hal-hal lain jika perlu. Objek penelitian yang menjadi rujukan analisis yaitu buku kumpulan puisi Malu Aku Jadi Orang Indonesia karya Taufiq Ismail. Objek yang digunakan dalam analisis puisi yaitu salah satu puisi dari buku kumpulan puisi Taufiq Ismail yang berjudul Malu Aku Jadi Orang Indonesia.

\section{Pembahasan}

Penelitian ini menganalisis struktur puisi yaitu struktur fisikdan struktur batin puisi. Objek yang digunakan sebagai objek analisis. Objek yang digunakan menggunakan salah satu puisi dari buku kumpulan puisi Taufiq Ismail yang berjudul Malu Aku Jadi Orang Indonesia yang terdiri dari empat bagian ditulis pada tahun 1998. Puisi yang terdapat pada buku kumpulan puisi ini adalah repsentase kejadian 
yang dialami pada tahun 1998 dan lebih banyak membicarakan tentang keadaan saat itu.

\section{Struktur Fisik Puisi}

Struktur fisik puisi Malu Aku Jadi Orang Indonesia karya Taufiq Ismail sebagai berikut:

\section{a. Diksi}

Diksi merupakan pengolahan atau pemilihan kata yang digunakan sehingga puisi memiliki nilai estetika yang tinggi. Analisis diksi puisi Malu Aku Jadi Orang Indonesia karya Taufiq Ismail sebagai berikut:

Langit-langit akhlak rubuh, di atas negeriku berserak-serak

Hukum tak tegak, doyong berderak-derak

Dari kutipan larik puisi tersebut terdapat diksi yang memiliki makna konotatif dan denotatif. Diksi yang memiliki makna denotatif seperti akhlak, negeriku, hukum, doyong. Dari kata akhlak memiliki arti perilaku atau budi pekerti. Kata negeriku memiliki arti tanah tempat tinggal suatu bangsa yang ditempati rakyat. Kata doyong memiliki arti condong, miring, atau hampir roboh tentang pohon, rumah, dan sebagainya. Kata hukum memiliki arti peraturan yang secara resmi dianggap mengikat dan telah disepakati. Diksi yang memiliki makna konotatif seperti kata langit, tegak, berserak-serak, berderak-derak. Kata langit memiliki arti ruang luas yang terbentang di atas bumi atau bisa juga diartikan sebagai keteguhan. Kata berserak-serak memiliki arti tidak karuan atau tersebar. Kata berderak-derak memiliki arti tiruan bunyi yang patah. Diksi yang ditemukan tersebut memiliki makna estetika untuk memperindah isi dari puisi.

Di negeriku, sekongkol bisnis dan birokrasi berterang-terang curang susah dicari tandingan, 
Di negeri anak lelaki anak perempuan, kemenakan, sерupu, dan сисu dimanja kuasa ayah, paman, kake, secara hancur-hancuran seujung kuku tak perlu malu

Dari kutipan larik puisi tersebut terdapat diksi yang memiliki makna konotatif dan denotatif. Diksi yang memiliki makna denotatif seperti bisnis, biroksasi, dan kuasa. Kata bisnis memiliki arti usaha komersial dalam dunia perdangan. Kata birokrasi memiliki arti sistem pemerintahan yang dijalankan oleh pegawai yang berpegang pada hirearki dan jenjang jabatan. Kata kuasa memiliki arti kemampuan atau kesanggupan. Diksi yang memiliki makna konotatif seperti malu dan kuku. Kata malu memiliki arti merasa tidak enak hati. Kata kuku memiliki arti kekuasaan atau lapisan tipis yang terletak pada ujung jari tangan dan kaki. Diksi yang ditemukan tersebut memiliki makna estetika untuk memperindah isi dari puisi.

\section{b. Imaji}

Imaji merupakan cara yang diguanakan oleh seoarang penyair dalam penggunaan indera manusia, seperti imaji penglihatan, imaji pendengaran, imaji perabaan, imaji pengecapan, imaji penciuman. Analisis imaji puisi Malu Aku Jadi Orang Indonesia karya Taufiq Ismail sebagai berikut:

\section{1) Imaji Penglihatan}

Imaji penglihatan adalah imaji yang digunakan oleh penyair menggunakan indera penglihatan. Analisis imaji penglihatan sebagai berikut:

Ada pula pembantahan terang-terangan yang merupakan dusta terangterangan di bawah cahaya surya terang-terangan, dan matahari tidak pernah dipanggil ke pengadilan sebagai saksi terang-terangan.

Dari kutipan larik puisi tersebut terdapat imaji penglihatan seperti pada larik di bawah cahaya surya terang-terangan merupakan suatu penggambaran yang dilakukan oleh penyair untuk mengajak pembaca seakan-akan melihat cahaya matahari atau cahaya surya dalam puisi. 


\section{2) Imaji Pendengaran}

Imaji pendengaran adalah imaji yang digunakan oleh penyair menggunakan indera pendengaran. Analisis imaji pendengaran sebagai berikut:

\section{Doyong berderak-derak}

Dari kutipan larik puisi tersebut terdapat imaji pendengaran seperti pada larik doyong berderak-derak. Doyong memiliki arti condong, hampir roboh dan berderak-derak memiliki arti bunyi dari suatu patahan seperti pohon. Maka dari itu dari kata berderak-derak menghasilkan bunyi dari pohon atau benda yang mulai roboh sehingga termasuk kepada imaji pendengaran.

\section{3) Imaji Perabaan}

Imaji perabaan merupakan imaji yang dapat dirasakan oleh indera peraba atau kulit manusia. Analisis imaji perabaan sebagai berikut:

\section{Dan kubenamkan topi baret di kepala}

Dari kutipan larik puisi tersebut terdapat imaji perabaan. Dari kutipan tersebut menjelaskan bahwa $a k u$ dalam puisi tersebut sedang meletakan topi di atas kepala. Maka dari itu kutpan tersebut termasuk kepada indera perabaan karena kulit menyentuh topi untuk ditaruh di kepala.

\section{4) Imaji Penciuman}

Imaji penciuman merupakan imaji yang berhubungan dengan gambaran yang dihasilkan dari indera penciuman. Analisis imaji penciuman sebagai berikut:

\section{Ciumlah harum aroma mereka punya jenazah}

Dari kutipan larik puisi tersebut terdapat imaji penciuman. Dari kutipan tersebut menjelaskan bahwa penyair seolah-olah menyuruh untuk mencium harum aroma jenazah kepada seseorang, maka dari itu harum merupakan bagian dari indera penciuman yang digunakan oleh manusia. 


\section{c. Kata Konkret}

Kata konkret merupakan cara yang dilakukan penyair dalam mengartikan suatu kata secara menyeluruh. Analisis kata konkret puisi Malu Aku Jadi Orang Indonesia karya Taufiq Ismail sebagai berikut:

Langit-langit akhlak rubuh, di atas negeriku berserak-serak hukum tak tegak, doyong berderak-derak, berjalan aku di Roxas Boulevard, Geylang Tahrir, dan Ginza berjalan aku di Dam, Champs Elysees dan Mesopotamia di sela khlayak aku berlindung di belakang hitam kacamata malu aku jadi orang Indonesia

Dari kutipan bait puisi tersebut terdapat kata konkret seperti negeriku, hukum, Indonesia mempunyai makna yang konkret setiap katanya, walau kata tersebur sudah disebutkan dalam diksi, namun kata tersebut memiliki makna yang menyeluruh untuk setiap bait puisi. Dalam kutipan bait tersebut merupakan bagian ke dua dari puisi Malu Aku Jadi Orang Indonesia yang diulang dibagian ke empat karena puisi Taufiq Ismail termasuk ke dalam puisi esai.

\section{d. Gaya Bahasa atau Majas}

Gaya bahasa atau majas merupakan penggunaan bahasa yang bersifat seolaholah menghidupan dan menimbulkan makna konotasi dengan menggunakan bahasa yang figuratif. Analisis gaya bahasa atau majas pada puisi Malu Aku Jadi Orang Indonesia karya Taufiq Ismail sebagai berikut:

\section{1) Majas Perbandingan}

Majas perbandingan merupakan majas yang digunakan untuk membandingkan suatu objek dengan objek lainnya. Analisis gaya bahasa perbandingan sebagai berikut:

\section{a) Majas Asosiasi}

Majas asosiasi merupakan penggunaan ungkapan dua objek berbeda, namun dianggap sama. Analisis majas asosiasi sebagai berikut: 
Kehidupan sehari-hari bagai jarum hilang menyelam di tumpukan jerami selepas menuai padi.

Dari kutipan tersebut terdapat majas asosiasi pada kata bagai yang menerangkan suatu perbandingan antara kehidupan dengan jarum yang dicari di tumpukan jerami, artinya kehidupan harus melewati dengan rasa kesabaran dan terus berusaha.

\section{b) Hiperbola}

Majas hiperbola adalah penggunaan majas yang memberikan kesan berlebihan. Analisis majas hiperbola sebagai berikut:

Di negeriku perhitungan suara pemilihan umum sangat-sangatsangat-sangat-sangat jelas penipuan besar-besaran tanpa seujung rambut pun bersalah perasaaan.

Dari kutipan tersebut terdapat majas hiperbola pada penggalan larik sangat-sangat-sangat-sangat-sangat termasuk ke dalam majas hiperbola karena memiliki kesan yang berlebihan dalam menyampaikan pesan yang begitu tidak sesuai dengan pola kalimat yang diharuskan.

\section{c) Eufeminisme}

Eufeminisme merupakan majas yang digunakan untuk menggantikan kata yang kurang etis dengan kata yang lebih halus. Analisis majas eufeminisme sebagai berikut:

Ciumlah harum aroma mereka punya jenazah

Dari kutipan tersebut terdapat majas eufeminisme karena terdapat kata yang hlebih halus seperti kata jenazah karena jenazah merupakan istilah yang digunakan untuk menyebut orang yang sudah meninggal dan terkesan dengan halus dibandingkan dengan mayat.

\section{2) Majas Penegasan}


Majas penegasan merupakan suatu majas yang digunakan penulis untuk mempengaruhi pembaca untuk menyetujui yang diungkapkan. Analisis gaya bahasa penegasan sebagai berikut:

\section{a) Majas Klimaks}

Majas klimaks merupakan majas yang digunakan untuk mengurutkan tingkatan dari rendah ke tinggi. Analisis majas klimaks sebagai berikut:

Di kedutaan besar anak presiden, anak mentri, anak jendral, anak sekjen, anak dirjen dilayani seperti presiden

Dari kutipan tersebut terdapat majas klimaks karena berurutan dari kedudukan yang lebih tinggi ke kedudukan rendah, dibuktikan dengan dari anak presiden sampai dirjen yang disebutkan secara berurutan.

\section{e. Rima atau Irama}

Rima atau irama merupakan pengolah kata dalam setiap lariknya sehingga terjadi persamaan bunyi baik di awal, tengah atau pada bagian akhir larik puisi. Analisis rima atau irama puisi Malu Aku Jadi Orang Indonesia karya Taufiq Ismail sebagai berikut:

\section{1) Rima Awal}

Rima awal merupakan rima yang terdapat pada awal kata. Analisis rima atau irama awal sebagai berikut:

berjalan aku di Roxas Boulevard, Geylang Tahrir, dan Ginza

berjalan aku di Dam, Champs Elysees dan Mesopotamia

Dari kutipan tersebut terdapat rima awal pada pada kata berjalan karena terdapat kesamaan pada segi kata, suku kata dan terletak di awal larik. Maka dari itu kutipan larik tersebut termasuk ke dalam rima awal.

\section{2) Rima Akhir}

Rima akhir merupakan rima yang terdapat pada akhir kata. Analisis rima atau irama akhir sebagai berikut: 
Ketika di pekalongan, SMA kelas tiga

Ke Wirconsin aku dapat beasiswa

Dari kutipan tersebut terdapat rima akhir yang memiliki kesamaan pada penggunaan sajak a-a. maka dari itu kutipan larik tersebut termasuk ke dalam rima akhir.

\section{f. Tipografi}

Tipografi merupakan aspek visual puisi dengan mengetahui tata hubungan dan tata baris dalam sebuah puisi. Analisis tipografi puisi Malu Aku Jadi Orang Indonesia karya Taufiq Ismail sebagai berikut:

\section{1) Menggunakan huruf kapital pada setiap awal larik}

Di negeriku, sekongkol bisnis dan birokrasi berterang-terang curang susah dicari tandingan,

Di negeri anak lelaki anak perempuan, kemenakan, sepupu, dan сиси dimanja kuasa ayah, paman, kake, secara hancur-hancuran seujung kuku tak perlu malu

Dari kutipan tersebut menjelaskan bahwa setiap awal larik menggunakan huruf kapital da nada pula yang menggunakan huruf kecil.

\section{2) Menggunakan tanda baca}

Di kedutaan besar anak presiden, anak mentri, anak jendral, anak sekjen, anak dirjen dilayani seperti presiden

Dari kutipan tersebut menjelaskan secara keseluruhan larik menggunakan tanda baca seperti koma untuk menjeda, tetapi ada pula yang tidak menggunakan tanda baca.

\section{Struktur Batin Puisi}

Struktur fisik puisi Malu Aku Jadi Orang Indonesia karya Taufiq Ismail sebagai berikut:

\section{a. Tema}


Tema merupakan menyampaikan gagasan yang dikembangkan melalui sajaksajaknya baik berupa makna setiap bait maupun secara keseluruhan. Analisis tema puisi Malu Aku Jadi Orang Indonesia karya Taufiq Ismail sebagai berikut:

\section{1) Tema Kedaulatan Rakyat}

Langit-langit akhlak rubuh, di atas negeriku berserak-serak hukum tak tegak, doyong berderak-derak, berjalan aku di Roxas Boulevard, Geylang Tahrir, dan Ginza berjalan aku di Dam, Champs Elysees dan Mesopotamia di sela khlayak aku berlindung di belakang hitam kacamata malu aku jadi orang Indonesia

Dari kutipan puisi tersebut memiliki tema kedaulatan rakyat di mana isi yang terdapat di dalam puisi menekankan kepada memberikan kritik untuk menentang kekuasaan yang tidak sesuai dengan aturan atau sewenang-wenang. Dengan adanya puisi dapat menyalurkan aspirasi rakyat bila secara tindakan dihiraukan.

\section{b. Rasa}

Rasa merupakan penyair membuat puisi dengan menyelipkan suatu sikap terhadap permasalahan yang terdapat dalam puisi. Analisis rasa puisi Malu Aku Jadi Orang Indonesia karya Taufiq Ismail sebagai berikut:

Langit-langit akhlak rubuh, di atas negeriku berserak-serak hukum tak tegak, doyong berderak-derak, berjalan aku di Roxas Boulevard, Geylang Tahrir, dan Ginza berjalan aku di Dam, Champs Elysees dan Mesopotamia di sela khlayak aku berlindung di belakang hitam kacamata malu aku jadi orang Indonesia

Dari kutipan puisi tersebut terdapat unsur rasa yang dituangkan penyair saat itu adalah kecewa, tidak enak hati, sedih karena puisi ini menerangkan tentang keadaan negara Indonesia yang tidak memiliki rasa ketidakadilan dalam kehidupan hanya orang-orang yang memiliki kedudukan 
saja yang menimkati kesenangan sehingga kondisi dalam cerita tersebut lebih menekankan kepada rasa kekecewaan seoarang rkyat kepada negaranya sendiri.

\section{c. Nada}

Nada merupakan penyaluran suatu sikap kepada pembaca yang berhubungan dengan tema dan rasa yang disampaikan. Analisis nada puisi Malu Aku Jadi Orang Indonesia karya Taufiq Ismail sebagai berikut:

Di kedutaan besar anak presiden, anak mentri, anak jendral, anak sekjen, anak dirjen dilayani seperti presiden, mentri, jendral, ekjen, dan dirjen sejati, agar orang tua mereka bersenang hati.

Dari kutipan tersebut menjelaskan tentang nada yang digunakan penyair ketika membuat puisi tersebut dengan nada mengkritik kepada orang yang dituju.

\section{d. Amanat}

Amanat merupakan menyampaikan maksud dan tujuan yang disampaikan kepada pembaca melalui pesan tersirat yang terdapat dalam isi puisi, Analisis amanat puisi Malu Aku Jadi Orang Indonesia karya Taufiq Ismail sebagai berikut:

Amanat yang dapat disampaikan dari puisi Malu Aku Jadi Orang Indonesia karya Taufiq Ismail adalah membuat perubahan kearah yang lebih baik agar tidak ada orang yang tertindas, terasingkan, dan tidak ada lagi ketidakadilan dalam masyarakat sehingga menciptakan masyarakat yang taat kepada aturan yang ditetapkan.

\section{Simpulan}

Dari hasil penelitian peneliti dapat menyimpulkan bahwa puisi memiliki struktur fisik dan batin karena strutur puisi sangat berpengaruh terhadap kualitas puisi yang akan dibuat. Struktur fisik puisi merupakan struktur pembangun puisi yang bersifat fisik atau nampak dalam bentuk susunan kata-katanya atau bisa dikatakan 
sebagai sarana yang digunakan oleh seoarang penyair untuk mengungkapkan hakikat puisi. Sedangkan strutur batin puisi merupakan merupakan struktur pembangun puisi yang membangun dari dalam.

Hasil dari analisis struktur fisik puisi berdasarkan diksinya terdapat lima diksi berkaitan dengan pemilihan kata yang digunakan penyair. Berdasarkan imaji terdapat dua imaji yang berkaiatan dengan alat indera manusia. Berdasarkan kata konkret terdapat tiga yang berkaiatan dengan pemaknaan kata secara menyeluruh. Berdasarkan gaya bahasa terdapat dua gaya bahasa seperti majas perbandingan dan majas penegasan. Berdasarkan rima atau irama terdapat dua berkaitan dengan sajak. Berdasarkan tipografi terdapat dua berkaitan dengan tata penulisan larik dan puisi. Hasil dari analisis struktur batin berdasarkan tema terdapat satu tema yang berkaitan dengan masalah yang diangkat dari puisi. Berdasarkan nada terdapat satu nada. Berdasarkan rasa terdapat tiga rasa yang dirakan penyair. Terdapat satu amanat mengenai pesan yang disampaikan.

\section{Daftar Pustaka}

Husein, Umar. 2005. Metode Penelitian Untuk Tesis dan Bisnis. Jakarta: Grafindo.

Ismail, Taufiq. 2008. Malu Aku Jadi Orang Indonesia. Jakarta Timur: PT Cakrawala Budaya Indonesia.

Kamilah, dkk. 2016. Puisi Siswa Kelas VIII A MTs Al-Khairiyah Tegalinggah: Sebuah Analisis Struktur Fisik dan Batin Puisi. E-Jurnal JPBSI. Universitas Pendidikan Ganesha. No 2 Vol 4 Hal 1-10. file:///C:/Users/User/Downloads/308084-1-SM.pdf.

Sulkifli dan Marwati. 2016. Kemampuan Menulis Puisi Siswa Kelas Viii Smp Negeri Satu Atap 3 Langgikima Kabupaten Konawe Utara. Jurnal Bastra. Pendidikan Bahasa dan Sastra Indonesia FKIP UHO. No. 1 Vol. 1 Hal 1-22. file:///C:/Users/User/Downloads/1058-3337-1-PB\%20(2).pdf. 
Sulaeman, Agus dan Goziyah. 2019. Metodologi Penelitian Bahasa dan Sastra. Jakarta Timur: Edu Pustaka.

Wahyuni Y, Sri dan Mohd. Harun. 2018. Analisis Struktur Fisik dan Struktur Batin Puisi Anak dalam Majalah Potret Anak Cerdas. Jurnal Master Bahasa. No. 2 Vol 6 Hal 115-125. file:///C:/Users/User/Downloads/11601-29534-1PB\%20(1).pdf.

Wirawan, Gunta. 2016. Analisis Struktural Antologi Puisi Hujan Lolos Disela Jari. $\begin{array}{llllll}\text { Jurnal JP-BSI. } & \text { No. } & 2 & \text { Vol } & 1 & \text { Hal }\end{array}$ https://drive.google.com/file/d/13GGWKTcIZthtEBgSa84fIGu4cbRB0wI/view? usp=drivesdk 